\title{
EGY HELY, AHOL A GYEREKEK NAGYON BOLDOGOK VOLTAK
}

\section{REKTOR ORSOLYA}

Az 1992/1993-as tanévben jártunk. A tanítóképző utolsó éve volt számomra. Volt sok elmélet, és volt egy kis gyakorlat is. Pozitívumként említhetem, hogy több helyen, többfélét láthattunk. De főleg frontális munka, levezényelt rajzolás, szigorú fegyelem, több-kevesebb mosoly, határozott óravezetés, ellentmondást nem türö, tekintélyt parancsoló, jó hírü pedagógusok, írók - költők arcképcsarnokával felékesített tantermek.

Választani kellett, hol töltjük el egy hónapos tanítási gyakorlatunkat. Én otthon szerettem volna lenni, és az egykori iskolámban megtanulni a tanítás mesterfogásait. Hallottam, hogy az egyik tanító - aki ugyan engem soha nem tanított - valami különleges módszer szerint szervezi óráit. Az a hír járta, hogy ott a gyerekek csoportokban ülnek, együtt oldhatnak meg feladatokat és nagyon jól érzik magukat. Ez csak a szóbeszéd volt, amit a lakótelepen hallott anyukám fiatal szülőktől, ismerösöktől. Sokan egy listáról is beszéltek, amelyre fel kell iratkozni, ha valaki ebbe a boldog közösségbe szeretné a gyermekét bejuttatni. Később azt is megtudtam, hogy alapítványi osztályról van szó, ahol egy jelképes összeget kell fizetni a szülőknek a különleges, humánus oktatásért.

Lelkes gyakornokként felhívtam egy régi osztálytársam anyukáját, aki ebben az osztályban dolgozott napközis nevelőként, és időpontot egyeztettem vele, hogy mikor mehetek be megbeszélni a gyakorlat részleteit.

Beléptem a terembe. Színes falak, vidám függöny, csoportokba rendezett padok, gyermekek által készített rajzok, applikációk és egy hatalmas színes szőnyeg. Ilyet még addig nem láttam. Megsejtettem, hogy miért szeretnék sokan, hogy ide járjon csemetéjük. Mindenképpen itt szerettem volna gyakorolni a tanítást. A két tanítónő büszkén vezetett végig a termen. Megmutatták a padokat, a csoportértékelő táblákat, a gyerekek rajzait. Meséltek arról, hogy a szülők segítettek abban, hogy ez a terem ennyire barátságos legyen. Elmondták, a módszer, aminek a segítségével vidáman és nagyon hatékonyan tanítják tanítványaikat, a humanisztikus - kooperatív tanítási modell. Erről nem tanultunk a föiskolán, pedig szakirodalma is van, a tanítók által csak „Benda Bibliának” nevezett tanári kézikönyv.

Felmentünk az igazgatónő irodájába. Őt is jól ismertem, hisz egykori fizikatanárom volt és egyben egy nagyon kedves osztálytársam anyukája. Megbeszéltük a gyakorlat időpontját és a másik osztályt, ahol szintén el kellett töltenem két hetet. Hiszen az egy hónapos gyakorlatból két hetet első évfolyamon, két hetet pedig harmadik vagy negyedik évfolyamon kellett teljesíteni. Nem éreztem semmit ab- 
ból, hogy esetleg gondot okozhat a kérésem. A föiskolán is örömmel fogadták a lehetőséget és több tanárom kérte, hogy meséljek majd az élményeimröl, mert érdekli őket is ez a tanítási modell.

Emlékeim szerint több hónap is eltelt mire elérkezett a gyakorlat első napja. Boldogan vonultam be az iskolába. Lejelentkeztem az igazgatónőnél, aki közölte velem, hogy melyik osztályban vár egy tanítónő bemutató órával. Én szóltam, hogy nem ezt beszéltük meg. A papíromon is szerepel, hogy a humanisztikus osztályban szeretném tölteni a gyakorlatom felét. Én magam sem értem, és vissza sem tudok emlékezni arra, hogy mertem megtenni, de nem mentem be a másik tanító bemutató órájára, hanem lázadó arccal berohantam a színes fészekbe és sírtam. Nem küldtek ki. Ezt sem tudom, hogy merték vállalni.

Hogy ők milyen beszélgetésen vettek részt utána az igazgatói irodában, arról nem meséltek, de engem behívatott Ági néni. Elmondtam, hogy nem véletlenül választottam ezt az osztályt, ezeket a pedagógusokat, és egy jól irányzott mondattal utaltam rá, hogy a tanítóképző föiskola oktatói várják a beszámolómat és nagy szolgálatot tehetne a Hriszto Botev Általános Iskola, ha engedélyezné gyakorlatom letöltését a humanisztikus osztályban. Meggyőztem, de elnézést kellett kérnem a másik tanítótól, akit pedig úgy gondolom, hogy nem csak én hoztam ebbe a kellemetlen helyzetbe. Ezeket az eseményeket csak azért írtam le, hogy érezhető legyen, mennyire nem volt még elfogadott ebben az időben a másként gondolkodás a tanításról ... pedig milyen régen voltak már ehhez képest a reformpedagógiai irányzatok! Különösen nehéz volt váltani valakinek, aki saját hazájában akart próféta lenni. Jutka néni és Marica néni nem kezdő és nem új pedagógusként kezdtek el dolgozni ezzel a módszerrel a Botev iskolában. Ott tanítottak, abban az iskolában sok-sok éve, és egyszer csak váltottak, megújultak vagy fejlődtek, nem is tudom, melyik szót használhatnám itt helyesen. Jutka néni így fogalmazott mikor megkérdeztük: ,Az igazság az, hogy kicsi gyermekkorom óta mindig szembe mentem a konvenciókkal, de a hivatásomban tizenöt év után kezdtek jelentkezni a szakmai kiégés tünetei, amiket felismertem magamon. (A pszichológia életközép krízisnek nevezi.) Ekkor döntöttem úgy, hogy vagy elhagyom a pályát, vagy változtatok. Az akkori politikai légkör kedvezett a szakmai megújulásnak. Tanultam, továbbképzéseken vettem részt, - némelyiket öneröböl finanszíroztam - rengeteg szakirodalmat elolvastam. Intellektuális értelemben rendkívül izgalmas időszak volt.”

Amit ez alatt a két hét tanítási gyakorlat alatt kaptam Isvánovits Judittól, az mind a mai napig elkísér és segít. Megalapozta hozzáállásomat a szakirodalomhoz, a folyamatos önképzéshez, a gyerekekhez és a szülökhöz. Egyes kollégákkal már nehezebb a dolgom, mint ahogy neki sem volt könnyü. Lehet, hogy huszonöt év tanítás után ezért is hagyta el a pályát. Egy igazán nagy pedagógiai tehetséget veszített el a „Kék Iskola”. Talán neki sem volt mindenre receptje. Most, húsz év tanítás után is értetlenül állok én is egy-egy kolléga megnyilatkozása, viselkedése előtt. Egy munkatársa mondta neki egy értekezleten, meglehetősen gúnyosan: „Egy fecs- 
ke nem csinál nyarat." Az én véleményem az, hogy szerencsére már erősen tavaszodik. Persze, pár évnek el kellett telnie. A nagy dolgokhoz, úgy tủnik, hosszabb évszakok kellenek.

Visszakanyarodom 1993-ba, ahhoz a két héthez, aminek minden részletére nem emlékszem ugyan, de a különleges, boldog, energiát adó érzés azóta is bennem lakik, amire tudom, hogy ott, a lila tanteremben tettem szert.

Akkora szerencsém volt, hogy részt vehettem egy szülöi értekezleten, amit ök szülökörnek neveztek. Körben ültünk, mindenki tegeződött egymással és olyan érzésekről beszélgettek, ami igazán meghitté tette a pedagógus-szülő és a szülőszülö viszonyt. Igen, emlékszem a témára is! Ki-ki, hogy van megelégedve a nevével? Olyan volt, mint egy önismereti kör. Máig nem tudom, hogy lehetett ilyen bensőséges kapcsolatrendszert kiépíteni egy szülöi közösségen belül. Még van mit tanulnom!

Megtapasztaltam, hogy a gyerekekkel sokat kell beszélgetni. Különösen arról, hogy érzik magukat, mi tetszett nekik egy órában és mi az, ami kevésbé. Ebből is építkezik a pedagógus. Ezt a célt szolgálta a reggeli beszélgető-kör is. Már a tanítás legelején tudtuk, hogy van-e valami gond, szomorúság, amit orvosolni kell, mielőtt munkához látunk. Azóta sem sajnálom az időt ettől. Sokszor kezdték így a gyerekek a mondandójukat: „Nekem az volt a legjobb”... és nekem, azóta is ez a legjobb része egy-egy órának.

Különösen intim viszonyba kerültem ezekkel a gyermekekkel ez alatt a két hét alatt. Elfogadták, hogy én tartsam a napi relaxációjukat. Judit néni erre is megtanított. Még a vizsgatanításomon is bevállaltam.

Azóta is őrzöm és rendszeresen használom az első drámajáték gyüjteményt, amit tőle kaptam. A címe: Add tovább! Ö továbbadta. Nem fukarkodott a tudással, amit birtokolt és birtokol ma is. Talán ettől igazán pedagógus valaki.

Csoda volt számomra a napi olvasókör. A gyerekekkel leültünk a szőnyegre. Mindenki hozhatott egy könyvet otthonról, és azt bemutatta, ajánlotta a többieknek, majd egy rövid részletet olvasott fel belöle. Közben a gyerekek megtanultak egymásra figyelni, és egymástól tanulni. Megérezhették, hogy ha nyitottak társaik felé, akkor bárkitől elleshetnek, elsajátíthatnak valamit. Ezzel ők maguk is értékesnek érezték magukat

Valóban! Ezek a gyerekek mások voltak, mint a szomszéd osztályokba járók. Nyitottak, közvetlenek, motiváltak, boldogok. Voltak pedagógusok, akik úgy látták őket, hogy rosszak és neveletlenek. Pedig csak szívesen megbeszéltek egymással fontos dolgokat, ügyesen és sokat kérdeztek. Nem viselte meg öket, ha tévedtek, mert a tévedés is emberi és elfogadható dolog volt, hiszen a tanítók se voltak tévedhetetlenek - ők ezt nyíltan vállalták, és nem érezték szégyennek. Gyerekek és felnőttek ezekben az osztályokban egyaránt tudták, hogy ez viszi előre tudásukat.

Miután tanítói diplomát szereztem, utána sem ért véget a kapcsolatom az osztállyal, sőt Jutka néni következő osztályába is bejártam, és szakköröket tartottam 
nekik, nyári táborokba vittem őket. A gyerekekkel való foglalkozások alkalmain keresztül szívhattam magamba a szellemiséget, amit tanítójuk képviselt. Jó visszaemlékezni ezekre a különleges egyéniségekre, akik valóban önmaguk lehettek már kisiskolásként is. Vannak olyanok is, akikkel 18-20 év után is még mindig tartom a kapcsolatot. Éppen néhány hónapja köszönt rám Veszprémben az egyetemen egy másik kislány édesapja.

Húgom - aki szintén megszállott pedagógus, abban az iskolában, amelynek pedagógiai szemléletében Istvánovits Judit érezhető nyomokat hagyott - megkérdezte tőle: Mit üzennél azoknak, akik még csak most lépnek ki a tanítóképző kapuján? Így válaszolt: Olvassák el József Attila Curriculum vitae-jéből az „én boldog pillanataimban gyermeknek érzem magam, és akkor derüs a lelkem, ha munkámban játékot fedezek fel..." kezdetü részt.

Játékosság, odafordulás, pedagógiai kreativitás, pszichológiai érzék, az önmüvelés igénye. Ezeknek csíráját Jutka néni ültette el bennem. Köszönöm! 